\title{
MODELING AND EXPERIMENTAL ANALYSIS OF Al2219/n-TiC/Gr POWDER-BASED PROCESS PARAMETERS USING DESIRABILITY APPROACH AND GENETIC ALGORITHM
}

\author{
MODELIRANJE IN EKSPERIMENTALNA ANALIZA A12219/n-TiC/Gr \\ PRAHU NA OSNOVI PROCESNIH PARAMETROV, UPORABE PRISTOPA \\ ZAŽELJENOSTI IN GENETSKIH ALGORITMOV
}

\author{
Ponnusamy Jeevanantham ${ }^{1}$, Krishnasamy Kumaresan², Zeelanbasha Noorbasha ${ }^{3}$ \\ ${ }^{1}$ United Institute of Technology, Department of Mechanical Engineering, India \\ 2Park College of Engineering and Technology, Department of Mechanical Engineering, India \\ ${ }^{3}$ Coimbatore Institute of Technology, Department of Mechanical Engineering, Coimbatore 641014, India \\ jeevananthamed@gmail.com
}

Prejem rokopisa - received: 2017-11-16; sprejem za objavo - accepted for publication: 2018-03-15

doi:10.17222/mit.2017.192

\begin{abstract}
In this experimental investigation, an Al2219 alloy matrix reinforced with $6 \%$ of titanium carbide (TiC particulates of $\leq 200 \mathrm{~nm}$ ) and $2 \%$ of graphite ( $\mathrm{Gr}$ particulates of $\leq 2 \mu \mathrm{m}$ ) were manufactured using a powder-metallurgy process. Mechanical properties such as microhardness and sintered density were improved by varying the production parameters such as compaction pressure (MPa), sintering temperature $\left({ }^{\circ} \mathrm{C}\right)$ and sintering time $(\mathrm{hr})$ at three different levels using the desirability approach integrated with a genetic algorithm (GA). The microstructures and phase compositions of the produced materials were examined with a field-emission scanning electron microscope (FSEM) and energy dispersive spectrometry (EDS). The probability greater than F-test values less than 0.05 indicates that the model terms are significant. The predicted desirability results revealed that the maximum density $\left(2.867 \mathrm{~g} / \mathrm{cm}^{3}\right)$ and microhardness $(140.20 \mathrm{HV})$ were achieved at optimized parameter values such as the compaction pressure A (479.45 MPa), sintering temperature B $\left(400.30{ }^{\circ} \mathrm{C}\right)$ and sintering time $\mathrm{C}(1.003 \mathrm{~h})$. The geneticalgorithm result showed a good agreement between the experimental and GA-predicted values.

Keywords: mechanical properties, nanoparticles, optimization, prediction, SEM - scanning electron microscope
\end{abstract}

Avtorji te eksperimentalne študije so izdelali kompozit s kovinsko osnovo iz aluminijeve zlitine Al2219, ojačano s $6 \%$ titan-karbida ( $\mathrm{TiC}$ z delci $\leq 200 \mathrm{~nm}$ ) in $2 \%$ grafita $(\mathrm{Gr} \mathrm{z}$ delci $\leq 2 \mu \mathrm{m})$. Kompozit so izdelali s postopkom metalurgije prahov. Mehanske lastnosti (mikrotrdoto) in sintrano gostoto so izboljšali s spreminjanjem procesnih parametrov, kot so tlak stiskanja $(\mathrm{MPa})$, temperatura in čas sintranja $\left({ }^{\circ} \mathrm{C}\right.$, ure). Eksperimente so izvajali na treh različnih nivojih. Uporabili so pristop zaželjenosti, integriran v genetski algoritem (GA). Mikrostrukturo in fazno sestavo kompozita so analizirali s pomočjo vrstičnega elektronskega mikroskopa na emisijo polja (FSEM; angl.: Field Emission Scanning Electron Microscope) in energijskega disperzijskega spektrometra (EDS; angl: Energy Dispersive Spectrometry). Večja verjetnost, da bodo vrednosti F-testa pod 0,05 , kaže na to, da so modelni parametri pomembni. Napovedani rezultati zaželjenosti so pokazali, da sta maksimalna gostota $\left(2,867 \mathrm{~g} / \mathrm{cm}^{3}\right)$ in mikrotrdota $(140,2 \mathrm{HV})$ doseženi pri optimiziranih vrednostih parametrov; to je tlaku stiskanja A $(479,45 \mathrm{MPa})$, temperaturi sintranja B $\left(400,3{ }^{\circ} \mathrm{C}\right)$ in času sintranja $\mathrm{C}(1,003 \mathrm{~h})$. Rezultat genetskega algoritma je tudi pokazal dobro ujemanje med eksperimentalnimi in GA vrednostmi.

Ključne besede: mehanske lastnosti, nanodelci, optimizacija, napoved, SEM - vrstični elektronski mikroskop

\section{INTRODUCTION}

In several industries, aluminium alloys are used as the base metals for the most particulate reinforcements due to their high strength, wear resistance and hardness. An aluminum alloy (AA) reinforced with ceramic nanoparticles was produced for a vast range of applications such as automobiles and aerospace engineering. ${ }^{1-2}$

There are several kinds of hard ceramic nanoparticles, e.g., $\mathrm{SiC}, \mathrm{B}_{4} \mathrm{C}, \mathrm{TiC}, \mathrm{TiB}_{2}, \mathrm{Al}_{2} \mathrm{O}_{3}$ and soft reinforcements, e.g., $\mathrm{MoS}_{2}$ or Gr, used as the reinforcements in aluminum alloys to improve the mechanical characteristics. ${ }^{3-7}$

However, many researchers suggested that titanium carbide is the most effective ceramic particle as that it has a good range of wettability and a high specific strength within an aluminum alloy. ${ }^{8-9}$ The machinability can be improved by adding graphite to a metal-matrix composite (MMC). ${ }^{10-11}$ The powder-processing technique adopted for the manufacture of hybrid metal-matrix composites (HMMC) compares to all the other HMMC fabrication processes due to its big advantages. ${ }^{12-14}$ The identified process parameters that influence the mechanical properties are the compaction pressure, the sintering time and the temperature used for the powder-based manufacturing method. ${ }^{12}$ An inappropriate selection of the powder-based process parameters leading to poor mechanical properties and sintered density, e.g., a low compaction pressure and sintered temperature, lead to a poor density and bonding nature; so a great attention to the selection of appropriate powder-metallurgy process parameters is required. ${ }^{13-15}$ 
Response-surface methodology (RSM) is an optimization tool adopted to understand the behaviour and interaction effects of the process parameters on the responses. ${ }^{16}$ Developed mathematical models were used for the prediction of MMC properties. ${ }^{17-18}$ Statistical analyses (ANOVA) carried out to identify the significance and influences of the parameters of the developed model, show a lack of fit and errors. ${ }^{19-20}$ The multi-objective genetic-algorithm technique was used to solve multi-objective optimization problems. ${ }^{21}$ The multi-objective genetic algorithm is an optimization technique, which helps to find the most effective responses in-between the upper and lower boundary conditions..$^{22}$ The highest objective of this study was to understand the powder-based process-parameter behaviour of an Al2219 alloy matrix reinforced with $\mathrm{TiC}$ and $\mathrm{Gr}$ particulates.

In the present work, $\mathrm{Al} 2219+6 \% \mathrm{n}-\mathrm{TiC}+2 \% \mathrm{Gr}$ hybrid metal-matrix composites were fabricated through the powder-metallurgy technique and the improvement in the mechanical properties was studied. Three production-process parameters, the compaction pressure (MPa), the sintering temperature $\left({ }^{\circ} \mathrm{C}\right)$ and the sintering time (h) with three different levels were considered for the responses of the microhardness (HV) and sintered density $\left(\rho_{\mathrm{s}}\right)$. The response-surface methodology (RSM) was utilized for experimental planning and analysis of variance. The formation of a surface defect on the produced samples was analysed using visual and ultrasonic inspection methods. Multi-objective optimization using a genetic algorithm was performed to find the optimal machining parameters in order to predict the maximum microhardness and sintered density. The maximum parameters influencing the multiple performance characteristics were investigated using ANOVA.

\section{EXPERIMENTAL PART}

\subsection{Experimental materials and set-up}

The hybrid metal-matrix composites were fabricated using the reinforcements such as $6 \%$ of nano-titanium carbide and $2 \%$ of graphite particulates. Commercially available Al-alloy 2219 with the average mesh size of $200 \mathrm{~nm}$ and a purity of $99.8 \%$ was used as the matrix material; TiC powder (a purity of $99.5 \%$, the average particle size of $=200 \mathrm{~nm}$ ) and Gr powder (a purity of $99.5 \%$ and the average particle size of $=2 \mu \mathrm{m}$ ) were used as hard reinforcements. The density values of the metal matrix and reinforcement particles (Al2219, TiC and $\mathrm{Gr}$ powders) were $2.84 \mathrm{~g} / \mathrm{cm}^{3}, 4930 \mathrm{~kg} / \mathrm{m}^{3}$ and $2.3 \mathrm{~g} / \mathrm{cm}^{3}$, respectively. Planetary-type mechanical ballmilling equipment was used to obtain a good mixture of the metal matrix and the reinforcement particles. The mixture of elemental powders was pre-heated at about $125{ }^{\circ} \mathrm{C}$ to remove the moisture present in the powder particles. The compaction process was carried out in an EN8 hardened-steel die with a diameter of $40 \mathrm{~mm}$ and a height of $32 \mathrm{~mm}$ using a hydraulic press with different pressures (350, 450 and 550) MPa and the maximum capacity of $70 \mathrm{t}$. Lubrication was used between the walls of the die using zinc stearate to achieve a better compact density. The compacted samples were kept in a furnace to undergo the sintering process at different temperatures $(400,500$ and 600$){ }^{\circ} \mathrm{C}$ and for different dwell periods (1, 2 and 3) h; they were later allowed to cool down to room temperature in the furnace itself.

\subsection{Microhardness and sintered density}

The mechanical properties such as microhardness and density were measured. Sintered samples were machined under testing conditions; microhardness values were measured on the polished surfaces after a $500 \mathrm{~g}$ load $\left(\mathrm{HV}_{500}\right)$ was applied for 5-10 $\mathrm{s}$ at three different locations, using a Vickers microhardness tester. The sintered density was measured using the Archimedes principle as per ASTM B962-08. ${ }^{22}$

\subsection{Experimental design}

The experimentations were carried out based on the central composite design (CCD) of the RSM in order to understand the influence of the process parameters on the responses needing less experimental work.

Table 1: Ranges of the process parameters

\begin{tabular}{|c|c|c|c|c|}
\hline \multirow{2}{*}{$\begin{array}{c}\text { Process pa- } \\
\text { rameters }\end{array}$} & \multirow{2}{*}{ Units } & \multicolumn{3}{|c|}{ Range of inputs } \\
\cline { 3 - 5 } & & -1 & 0 & 1 \\
\hline $\mathrm{A}$ & $\mathrm{MPa}$ & 350 & 450 & 550 \\
\hline $\mathrm{B}$ & ${ }^{\circ} \mathrm{C}$ & 400 & 500 & 600 \\
\hline $\mathrm{C}$ & $\mathrm{hr}$ & 1 & 2 & 3 \\
\hline
\end{tabular}

Table 2: CCD with responses

\begin{tabular}{|c|c|c|c|c|}
\hline $\mathrm{A} / \mathrm{MPa}$ & $\mathrm{B} /{ }^{\circ} \mathrm{C}$ & $\mathrm{C} / \mathrm{h}$ & $\mathrm{HV}_{500}$ & $\rho_{\mathrm{s}} / \mathrm{g} \mathrm{cm}^{-3}$ \\
\hline 450 & 500 & 2 & 120.36 & 2.71 \\
\hline 450 & 500 & 3 & 123.6 & 2.75 \\
\hline 450 & 600 & 2 & 118.72 & 2.69 \\
\hline 450 & 500 & 2 & 121.4 & 2.71 \\
\hline 450 & 400 & 2 & 129.6 & 2.79 \\
\hline 450 & 500 & 2 & 123.42 & 2.74 \\
\hline 450 & 500 & 2 & 122.56 & 2.73 \\
\hline 450 & 500 & 1 & 127.6 & 2.77 \\
\hline 350 & 500 & 2 & 117.8 & 2.64 \\
\hline 350 & 400 & 1 & 130.6 & 2.8 \\
\hline 550 & 400 & 3 & 132.6 & 2.81 \\
\hline 450 & 500 & 2 & 121.12 & 2.73 \\
\hline 550 & 600 & 1 & 117.2 & 2.62 \\
\hline 350 & 600 & 3 & 116.7 & 2.61 \\
\hline 550 & 500 & 2 & 132.6 & 2.75 \\
\hline
\end{tabular}

CCD input parameters consisting of one replicate of star and axial points, five centre points and ten non-cantered points were preferred for developing the matrix. The ranges of the process parameters and the CCD with responses are given in Tables $\mathbf{1}$ and $\mathbf{2}$. 


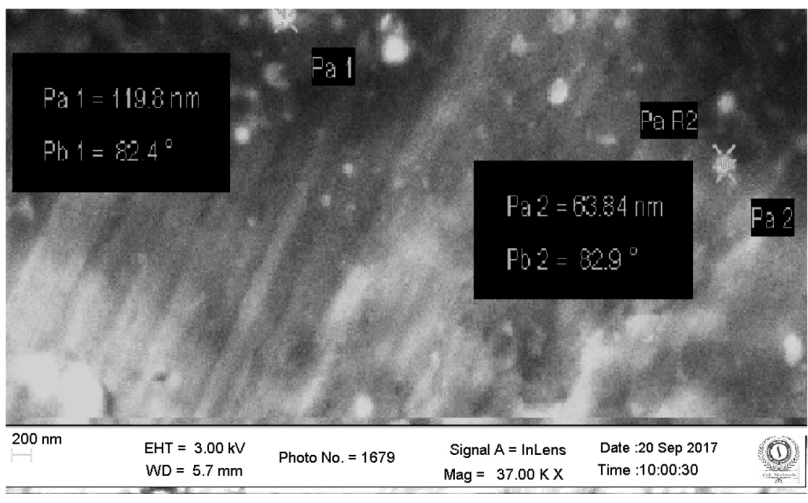

Figure 1: FESEM micrograph

\subsection{FESEM and EDS analyses}

The FESEM microstructural analysis indicates that the manufactured nanocomposite samples have an even scattering of the reinforcement particles - Al2219+6\% $\mathrm{n}-\mathrm{TiC}+2 \% \mathrm{Gr}$ (Figure 1). Also, Figure 2 depicting the EDS spectrum indicates that aluminium (Al), copper $(\mathrm{Cu})$ and iron $(\mathrm{Fe})$ peaks significantly confirm the A12219 presence. It is apparent from Figure 3 that all the nanocomposites display aluminium $(\mathrm{Al})$, copper $(\mathrm{Cu})$ and iron (Fe) peaks confirming Al2219 along with the presence of $\mathrm{Ti}$ and $\mathrm{C}$ peaks corresponding to $\mathrm{n}-\mathrm{TiC}$ in the case of $\mathrm{Al} 2219+6 \% \mathrm{n}-\mathrm{TiC}+2 \% \mathrm{Gr}$.

\section{RESULTS AND DISCUSSION}

\subsection{Response-surface methodology}

The effective optimization software tool Design Expert version 10 was used for the statistical analysis. Coefficients of the values were calculated to observe the significance of the developed models. The F-values for the model microhardness (HV) equal to 13.83 and sintered density $\left(\rho_{\mathrm{s}}\right)$ of 23.20 indicate that the developed parameters are significant; on the other hand, the values of the lack of fit for HV equal to 5.44 and $\rho_{\mathrm{s}}$ of 2.98 show that they are not significant compared to the pure error. An insignificant lack of fit is good for the models. Statis-

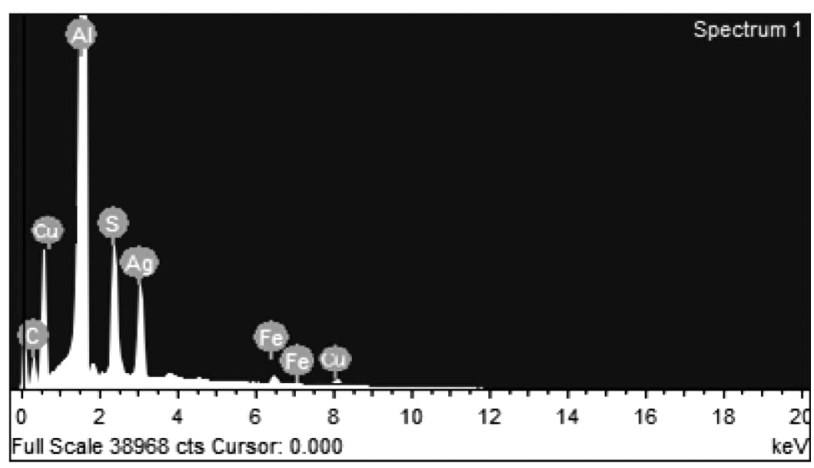

Figure 2: EDS graph of A12219

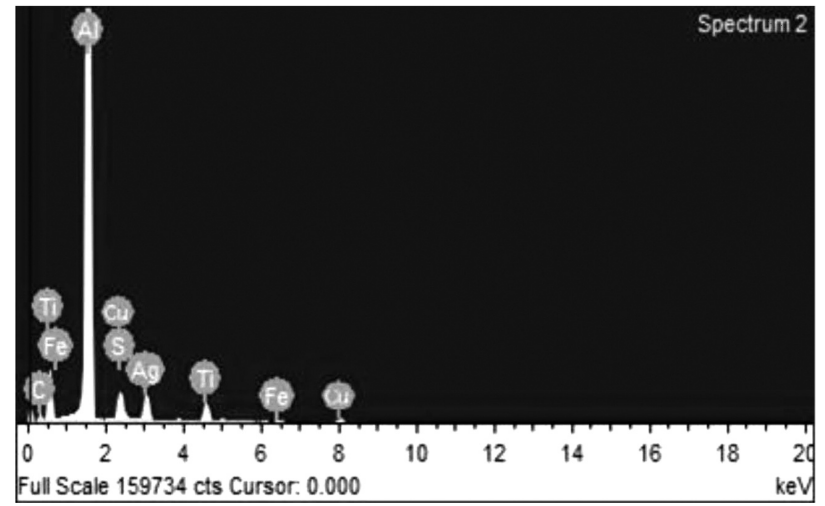

Figure 3: EDS graph of $\mathrm{Al} 2219+\mathrm{n}-\mathrm{TiC}+\mathrm{Gr}$

tical measures of $\mathrm{R}^{2}$ for $\mathrm{HV}(91 \%)$ and $\rho_{\mathrm{s}}(97 \%)$ show that the model is fitted into the regression line.

The various noted parametric interactions affecting the microhardness of the sintered composites are shown in Figure 4. By increasing the compaction pressure, there was a significant increase in the microhardness. An inappropriate selection of the sintering temperature and sintering time has a negative influence on the hardness. The hardness drops when the sintering temperature increases above the eutectic point of the matrix material. The heat absorption of the reinforcement material, especially at higher temperatures, results in a reduced matrix flow and a subsequent reduction in the hardness. The compaction pressure is vital for the surface hardness of aluminium composites. An inappropriate selection of the sintering time and temperature leads to an unusual material grain growth, thus reducing the mechanical property of the material.

It is apparent from Figures $\mathbf{4}$ and $\mathbf{5 a}$ that an increase in the compaction pressure (350 to 550) MPa significantly increases the microhardness; but Figures $\mathbf{4}$ and $\mathbf{5 b - 5}$ show that the sintering density and time have an inverse relationship with the compaction pressure, i.e.,

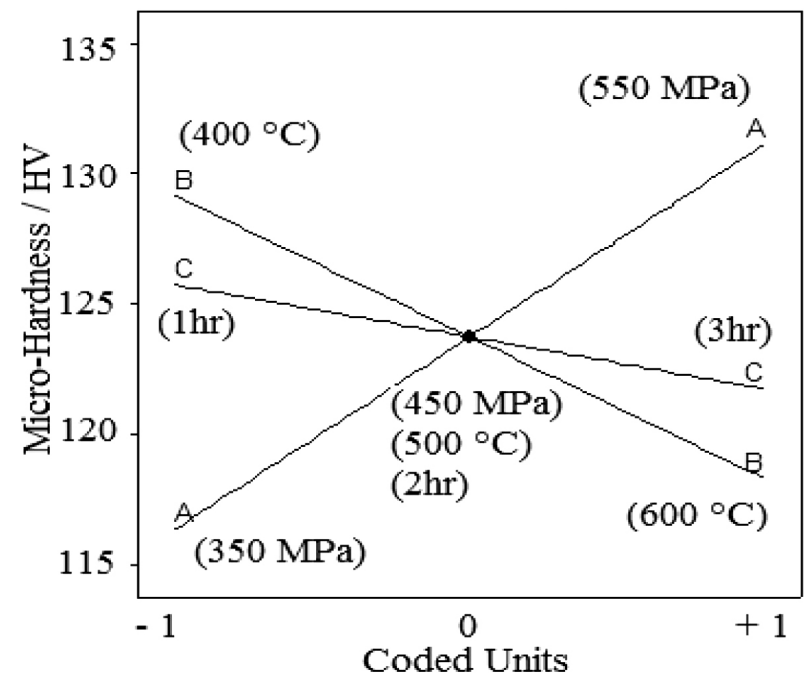

Figure 4: Perturbation of microhardness 

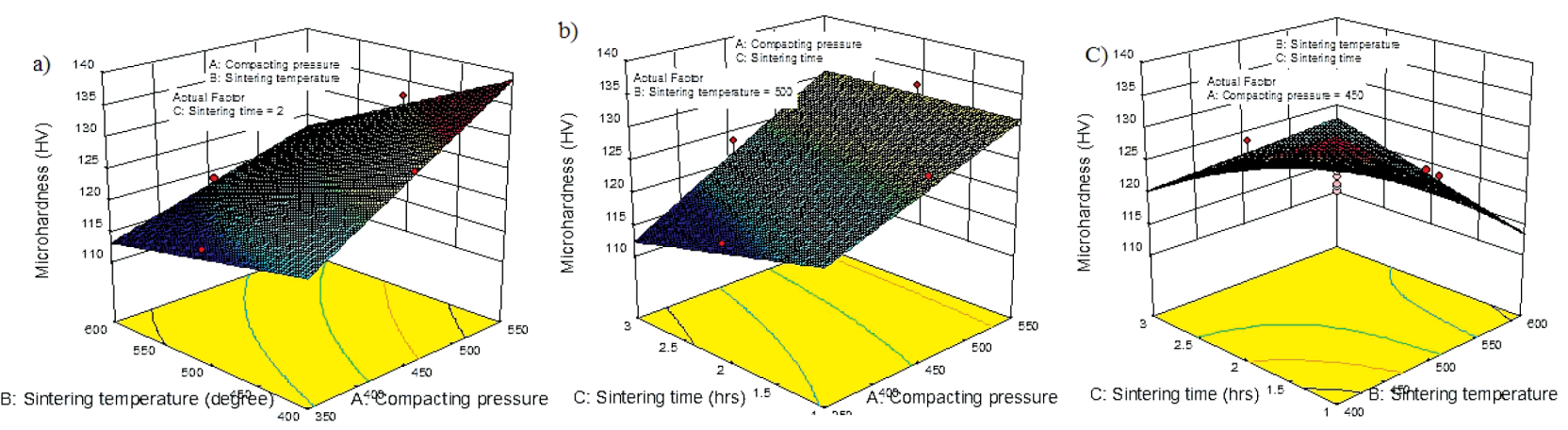

Figure 5: a) to c) Influences on the microhardness

the microhardness decreases with an increase in the sintering temperature and time; thus, the maximum microhardness can be attained at a higher compaction pressure (500-550) $\mathrm{MPa}$, and lower sintering temperature $\left(400-450{ }^{\circ} \mathrm{C}\right)$ and time $(1-1.5 \mathrm{~h})$ for $\mathrm{Al} 2219+6 \%$ $\mathrm{n}-\mathrm{TiC}+2 \%$ Gr. The developed mathematical regression model for the microhardness $(2 \mathrm{FI})$ is given below in Equation (1):

$\mathrm{HV}=152.9028333+0.15505 * \mathrm{~A}-0.083025 * \mathrm{~B}-$ $44.3575 * \mathrm{C}-2.37 \mathrm{E}-04 * \mathrm{~A} * \mathrm{~B}+0.01885 * \mathrm{~A} * \mathrm{C}+$ $0.06775 * \mathrm{~B} * \mathrm{C}$

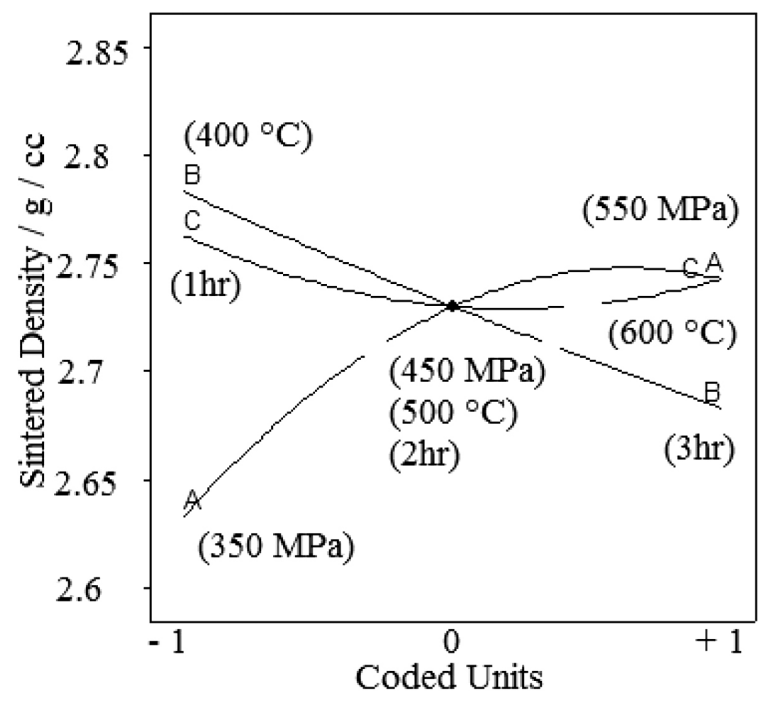

The effects of the compaction and sintered parameters on the sintered density are shown in Figure 6. The graph clearly shows that the compaction pressure increases with an increase in the sintered density, which clearly ensures a better particle dispersion and better particle bonding. Indirect effect plots are also taken into account with regard to the effect of the compaction pressure on the density. It is possible to achieve $95 \%$ of the theoretical density for $550 \mathrm{MPa}$. A low compaction pressure relatively scatters the influence of density. A high compaction pressure increases the strength of the compaction with a higher density shown in Figure 7a. It is clear from the interaction plot that the compaction pressure has a positive effect on the sintered density. The contribution ratio of the analysis of variance shows a minimum influence on the sintering temperature while increasing the sintered density. The sintering process is performed due to a diffusion of atoms with a good bonding strength in the grains.

Figures 6 and 7a show that an increase in the compaction pressure (350 to 550) MPa results in a significant increase in the sintered density. However, Figures 6 and 7b-7c show that the sintering density and time are inversely proportional to the compaction pressure, i.e., the microhardness decreases with an increase in the sintering temperature and, subsequently, the microhardness decreases with the optimum sintering time (1.5 h to $2 \mathrm{~h}$ ). Thus, the maximum sintered density can be attained at the optimum sintering time and a lower sintered density

Figure 6: Perturbation of the sintered density
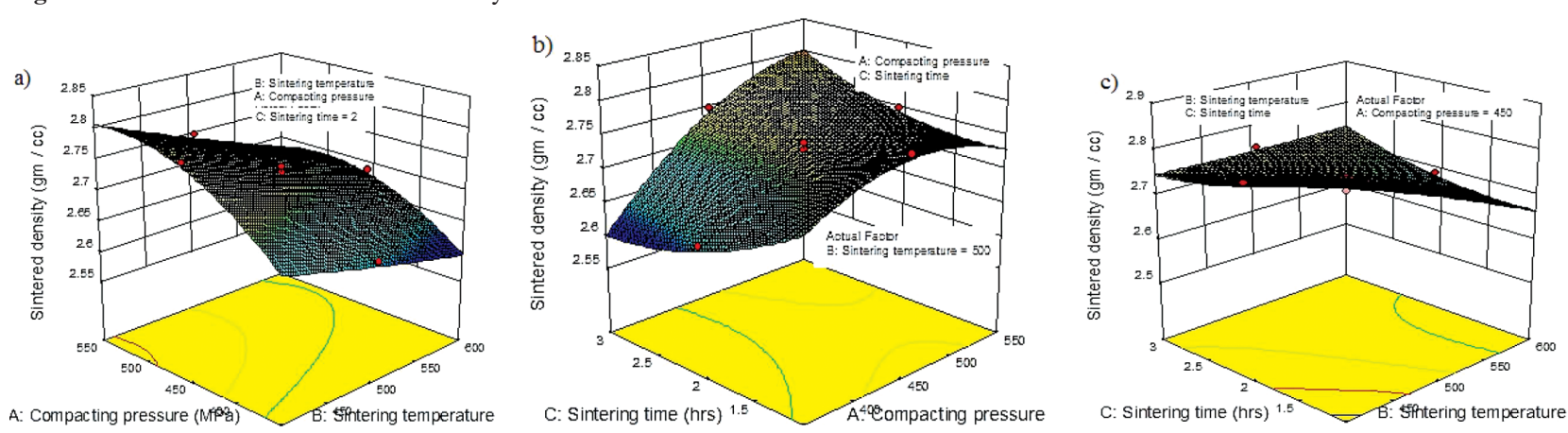

Figure 7: Effect on the sintered density 


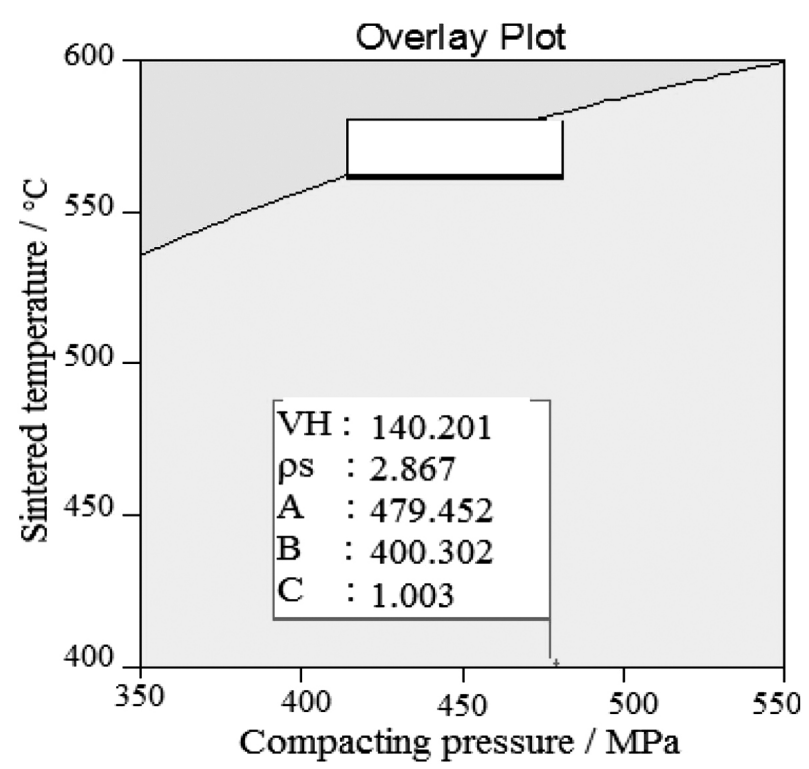

Figure 8: Overlay plot of desirability

at the higher compaction pressure for the production of $\mathrm{Al} 2219+6 \% \mathrm{n}-\mathrm{TiC}+2 \% \mathrm{Gr}$.

The developed mathematical regression model for the sintered density (a linear regression model) is given below in Equation (2).

Ts $=2.745906863+3.94 \mathrm{E}-03 * \mathrm{~A}-1.34 \mathrm{E}-03 * \mathrm{~B}-$ $0.554264706 * \mathrm{C}-1.00 \mathrm{E}-06 * \mathrm{~A} * \mathrm{~B}+4.50 \mathrm{E}-04 *$ $\mathrm{A} * \mathrm{C}+5.00 \mathrm{E}-04 * \mathrm{~B} * \mathrm{C}-4.21 \mathrm{E}-06 * \mathrm{~A}^{2}+2.94 \mathrm{E}$ $-07 * B^{2}+0.022941176 * C^{2}$

It is clear from the overlay plot in Figure 8 that the maximum microhardness (140.20 HV) and the sintered density $\left(2.867 \mathrm{~g} / \mathrm{cm}^{3}\right)$ can be attained for the production-process parameters such as the compaction pressure of $479.45 \mathrm{MPa}$, the sintering temperature of $400.30{ }^{\circ} \mathrm{C}$

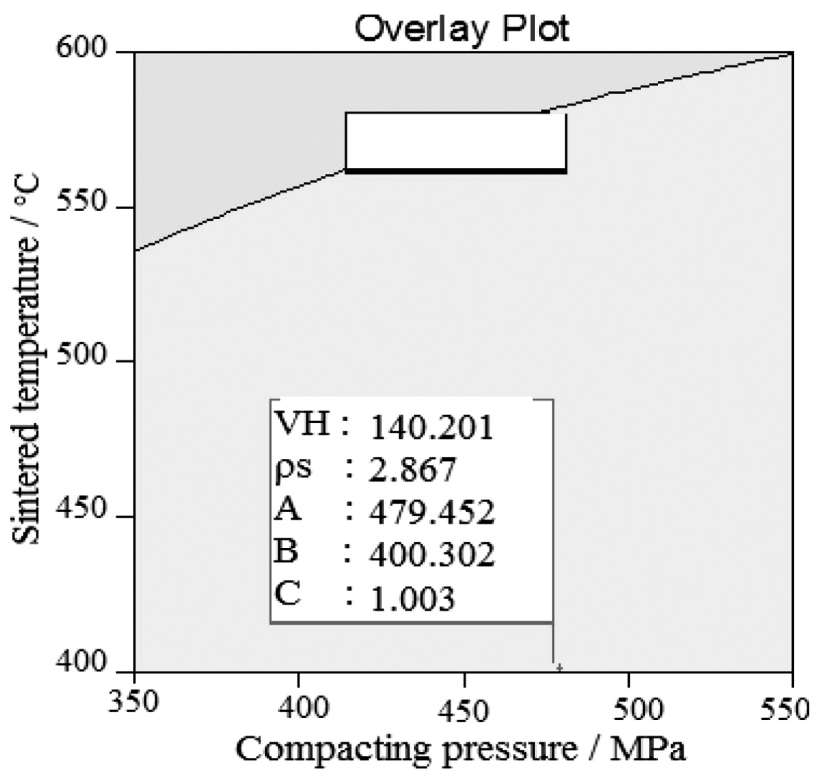

Figure 9: Pareto optimal frontier chart and the sintering time of $1.003 \mathrm{~h}$ at the maximum desirability of 1 . The desirability-analysis results show the values of the maximum microhardness and sintered density.

\subsection{Genetic algorithm}

In this study, a multi-objective genetic algorithm was adopted to solve the multi-objective optimization problem. Constraint limits were applied to the microhardness (a 2FI model) and sintered density (a linear model) to predict the optimal relationships between the production-process parameters (A, B and $\mathrm{C}$ ) and the responses ( $\mathrm{HV}$ and $\rho_{\mathrm{s}}$ ). The models were input into the GA multi-optimization tool in MATLAB Version R2016b to predict the maximum responses. The functions given are: Maximize the prediction of $\mathrm{HV}$

Maximize the prediction of $\rho_{\mathrm{s}}$ Parameter ranges: A (350-550 $\mathrm{MPa})$

$$
\begin{aligned}
& \mathrm{B}\left(400-600{ }^{\circ} \mathrm{C}\right) \\
& \mathrm{C}(1-3 \mathrm{~h})
\end{aligned}
$$
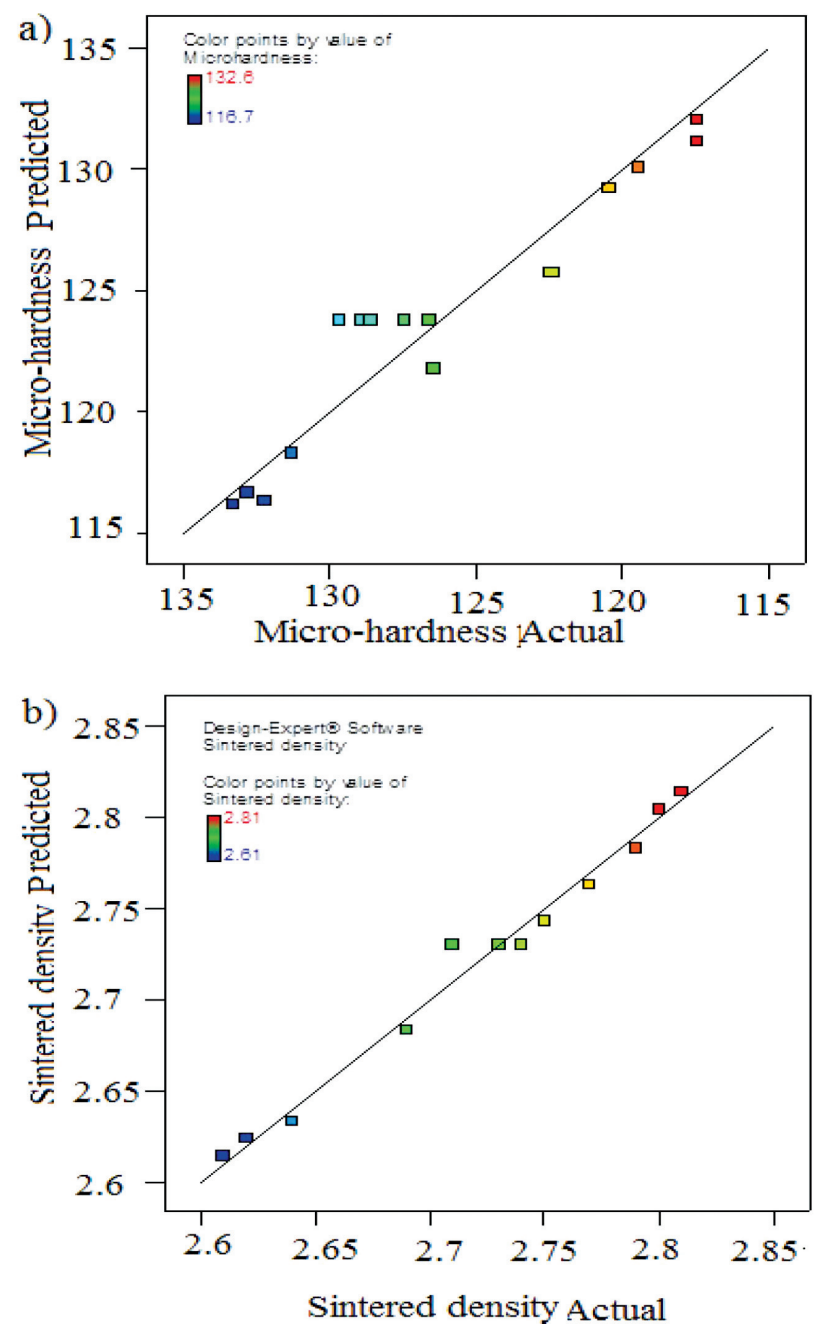

Figure 10: Prediction versus actual values 
Figure 8 indicates that the points are well distributed in the Pareto optimal frontier chart, which shows that the predicted values are in the range of desired optimized values. The GA predicted set of 18 non-interference solutions are presented in Table 3 .

Table 3: GA Pareto predicted values

\begin{tabular}{|c|c|c|c|c|}
\hline $\mathrm{A} / \mathrm{MPa}$ & $\mathrm{B} /{ }^{\circ} \mathrm{C}$ & $\mathrm{C} / \mathrm{h}$ & $\mathrm{HV}_{500}$ & $\rho_{\mathrm{s}} / \mathrm{g} \mathrm{cm}^{-3}$ \\
\hline 520.14 & 400.77 & 1.001 & 143.36 & 2.858 \\
\hline 502.95 & 400.74 & 1.001 & 142.01 & 2.864 \\
\hline 510.65 & 400.75 & 1.001 & 142.62 & 2.861 \\
\hline 509.11 & 400.76 & 1.001 & 142.49 & 2.862 \\
\hline 518.38 & 400.76 & 1.001 & 143.22 & 2.859 \\
\hline 516.10 & 400.76 & 1.001 & 143.04 & 2.860 \\
\hline 517.87 & 400.76 & 1.001 & 143.18 & 2.859 \\
\hline 516.99 & 400.78 & 1.003 & 143.10 & 2.859 \\
\hline 503.45 & 400.75 & 1.003 & 142.04 & 2.863 \\
\hline 518.90 & 400.77 & 1.001 & 143.26 & 2.859 \\
\hline 514.96 & 400.77 & 1.001 & 142.95 & 2.860 \\
\hline 508.62 & 400.75 & 1.001 & 142.45 & 2.862 \\
\hline 507.83 & 400.77 & 1.001 & 142.39 & 2.862 \\
\hline 513.76 & 400.74 & 1.001 & 142.86 & 2.860 \\
\hline 504.61 & 400.76 & 1.001 & 142.14 & 2.863 \\
\hline 512.23 & 400.75 & 1.001 & 142.74 & 2.861 \\
\hline 502.16 & 400.73 & 1.001 & 141.95 & 2.864 \\
\hline 500.00 & 400.70 & 1.001 & 141.79 & 2.864 \\
\hline
\end{tabular}

It is confirmed that all the optimized non-interference solutions are similarly better with no impediment to both the microhardness and sintered density. The GA operating parameters chosen are the population size (100), the population fraction $(0.35)$ and the crossover fraction (0.8). Figures 9a and 9b show that the GA prediction versus the experimental scatter plots revealed that the conceivable outcomes of the expectation error would be fewer.

\section{CONCLUSIONS}

An integrated approach using the RSM and multi-objective GA was employed to predict the responses by optimizing the production-process parameters. From this investigation, the following conclusions were drawn:

- The developed regression models for HV (2FI) and $\rho_{\mathrm{s}}$ (linear) show a good agreement between the process parameters and responses.

- The maximum microhardness (140.20 HV) and sintered density $\left(2.867 \mathrm{~g} / \mathrm{cm}^{3}\right)$ can be attained for the production-process parameters such as the compaction pressure $(479.45 \mathrm{MPa})$, sintering temperature $\left(400.30^{\circ} \mathrm{C}\right)$ and sintering time $(1.003 \mathrm{~h})$ at the maximum desirability of 1 .

- The set of the Pareto predicted values were verified and it was found that the eighteen sets of the optimized and predicted values are equally good, and the error falls in the range of $0.45-1.2$, showing a good agreement.
- The results revealed that the integrated approach of the RSM and GA was a reliable methodology for the prediction of a desired high-quality manufacturing process.

\section{REFERENCES}

${ }^{1}$ M. Cabeza, I. Feijoo, P. Merino, G. Pena, M. C. Pérez, S. Cruz, P. Rey, Effect of high energy ball milling on the morphology, microstructure and properties of nano-sized TiC particle-reinforced 6005A aluminium alloy matrix composite, Powder Technology, 321 (2017), 31-43, doi:10.1016/j.powtec.2017.07.089

${ }^{2}$ N. Selvakumar, P. Narayanasamy, Optimization and effect of weight fraction of $\mathrm{MoS}_{2}$ on the tribological behavior of $\mathrm{Mg}-\mathrm{TiC}-\mathrm{MoS}_{2}$ hybrid composites, Tribology Transactions., 59 (2016) 4, 733-74, doi:10.1080/10402004.2015.1110866

${ }^{3}$ P. Narayanasamy, N. Selvakumar, P. Balasundar, Effect of hybridizing $\mathrm{MoS}_{2}$ on the tribological behaviour of $\mathrm{Mg}-\mathrm{TiC}$ composites, Transactions of the Indian Institute of Metals, 68 (2015) 5, 911-925, doi:10.1007/s12666-015-0530-Z

${ }^{4}$ P. Ravindran, K. Manisekar, P. Rathika, P. Narayanasamy, Tribological properties of powder metallurgy - Processed aluminium self-lubricating hybrid composites with $\mathrm{SiC}$ additions, Materials and Design, 45 (2013), 561-570, doi:10.1016/j.matdes.2012.09.015

${ }^{5}$ D. D. Majumdar, D. P. Mondal, A. R. Chowdhury, H. Rao, J. D. Majumdar, Studies on titanium cenosphere composite developed by powder metallurgy route, Advanced Materials Research, 1139 (2016), 55-58, doi:10.4028/www.scientific.net/AMR.1139.55

${ }^{6}$ O. O. de Araújo Filho, E. R. de Araújo, H. M de Lira, C. H Gonzalez, N. Silva, S. L. Urtiga Filho, Manufacturing of AA2124 aluminum alloy metal matrix composites reinforced by silicon carbide processed by powder metallurgy techniques of high energy ball milling and hot extrusion, Materials Science Forum, 899 (2017), 25-30, doi:10.4028/www.scientific.net/MSF.899.25

${ }^{7}$ E. Ghasali, R. Yazdani-rad, K. Asadian, T. Ebadzadeh, Production of Al-SiC-TiC hybrid composites using pure and 1056 aluminum powders prepared through microwave and conventional heating methods, Journal of Alloys and Compounds, 690 (2017), 512-518, doi:10.1016/j.jallcom.2016.08.145

${ }^{8}$ N. Selvakumar, M. Sivaraj, S. Muthuraman, Microstructure characterization and thermal properties of Al-TiC sintered nano composites, Applied Thermal Engineering, 107 (2016), 625-632, doi:10.1016/j.applthermaleng.2016.07.005

${ }^{9}$ K. R. Kumar, K. Kiran, V. S. Sreebalaji, Micro structural characteristics and mechanical behaviour of aluminium matrix composites reinforced with titanium carbide, Journal of Alloys and Compounds, 723 (2017), 795-801, doi:10.1016/j.jallcom.2017.06.309

${ }^{10}$ P. Suresh, K. Marimuthu, S. Ranganathan, T. Rajmohan, Optimization of machining parameters in turning of Al-SiC-Gr hybrid metal matrix composites using grey-fuzzy algorithm, Transactions of Nonferrous Metals Society of China, 24 (2014) 9, 2805-2814, doi:10.1016/S1003-6326(14)63412-9

${ }^{11}$ S. Singh, M. Garg, N. K. Batra, Analysis of dry sliding behavior of A12O3/B4C/Gr aluminum alloy metal matrix hybrid composite using taguchi methodology, Tribology Transactions, 58 (2015) 4, 758-765, doi:10.1080/10402004.2015.1015757

${ }^{12} \mathrm{~K}$. Thiruppathi, S. Raghuraman, Investigations on the influence of mechanical behaviour of copper aluminium nickel powder compacts processed through powder metallurgy, Innovative Design and Development Practices in Aerospace and Automotive Engineering, (2017), 281-292, doi:10.1007/978-981-10-1771-1_31

${ }^{13}$ G. Uzun, U. Gokmen, H. Cinici, M. Turker, Effect of cutting parameters on the drilling of ALSI7 metallic foams, Mater. Tehnol., 51 (2017) 2, 19-24, doi:10.17222/mit.2015.106

${ }^{14}$ T. Varol, A. Canakci, S. Ozsahin, Artificial neural network modeling to effect of reinforcement properties on the physical and mechanical 
properties of $\mathrm{A} 12024-\mathrm{B}_{4} \mathrm{C}$ composites produced by powder metallurgy, Composites Part B: Engineering, 54 (2013), 224-233

${ }^{15}$ S. Chauhan, V. Verma, U. Prakash, P. C. Tewari, D. Khanduja, Analysis of powder metallurgy process parameters for mechanical properties of sintered Fe-Cr-Mo alloy steel, Materials and Manufacturing Processes, 32 (2017) 5, 537-541

${ }^{16}$ V. Kumar, V. Kumar, K. K. Jangra, An experimental analysis and optimization of machining rate and surface characteristics in WEDM of Monel-400 using RSM and desirability approach, Journal of Industrial Engineering International, 11 (2015) 3, 297-307, doi:10.1007/s40092-015-0103-0

${ }^{17}$ K. Shirvanimoghaddam, H. Khayyam, H. Abdizadeh, M. K. Akbari, A. H. Pakseresht, F. Abdi, M. Naebe, Effect of $\mathrm{B}_{4} \mathrm{C}, \mathrm{TiB}_{2}$ and $\mathrm{ZrSiO}_{4}$ ceramic particles on mechanical properties of aluminium matrix composites: experimental investigation and predictive modelling, Ceramics International, 42 (2016) 5, 6206-6220

${ }^{18}$ T. Rajmohan, K. Palanikumar, S. Prakash, Grey-fuzzy algorithm to optimise machining parameters in drilling of hybrid metal matrix composites, Composites Part B: Engineering, 50 (2013), 297-308, doi:10.1016/j.compositesb.2013.02.030

${ }^{19}$ M. O. Shabani, A. Mazahery, The GA optimization performance in the microstructure and mechanical properties of MMNCs, Transactions of the Indian Institute of Metals, 65 (2012) 1, 77-83, doi:10.1007/s12666-011-0110-9

${ }^{20}$ L. M. P. Ferreira, E. Bayraktar, I. Miskioglu, M. H. Robert, Influence of nanoparticulate and fiber reinforcements on the wear response of multiferroic composites processed by powder metallurgy, Advances in Materials and Processing Technologies, 3 (2017) 1, 23-32

${ }^{21}$ B. Senthilkumar, T. Kannan, R. Madesh, Optimization of flux-cored arc welding process parameters by using genetic algorithm, The International Journal of Advanced Manufacturing Technology, (2015), 1-7, doi:10.1007/s00170-015-7636-7

${ }^{22}$ N. Zeelanbasha, V. Senthil, B. Sharon Sylvester, N. Balamurugan, Modeling and experimental investigation of LM26 pressure die cast process parameters using multi objective genetic algorithm (moga), METABK, 56 (2017) 3-4, 307-310 